\title{
Cyanobacterial Diazotrophy and Earth's Delayed Oxygenation
}

\author{
Stephanie L. Olson ${ }^{*}$, Christopher T. Reinhard ${ }^{2}$ and Timothy W. Lyons ${ }^{1}$ \\ ${ }^{1}$ Department of Earth Sciences, University of California, Riverside, Riverside, CA, USA, ${ }^{2}$ School of Earth and Atmospheric \\ Sciences, Georgia Institute of Technology, Atlanta, GA, USA
}

The redox landscape of Earth's ocean-atmosphere system has changed dramatically throughout Earth history. Although Earth's protracted oxygenation is undoubtedly the consequence of cyanobacterial oxygenic photosynthesis, the relationship between biological $\mathrm{O}_{2}$ production and Earth's redox evolution remains poorly understood. Existing models for Earth's oxygenation cannot adequately explain the nearly 2.5 billion years delay between the origin of oxygenic photosynthesis and the oxygenation of the deep ocean, in large part owing to major deficiencies in our understanding of the coevolution of $\mathrm{O}_{2}$ and Earth's key biogeochemical cycles (e.g., the $\mathrm{N}$ cycle). For example, although possible links between $\mathrm{O}_{2}$ and $\mathrm{N}$ scarcity have been previously explored, the consequences of $\mathrm{N}_{2}$ limitation for net biological $\mathrm{O}_{2}$ production have not

OPEN ACCESS

Edited by:

Robert Eugene Blankenship, Washington University in St. Louis,

USA

Reviewed by:

John Stolz,

Duquesne University, USA Katja Meyer,

Willamette University, USA

*Correspondence: Stephanie L. Olson solso002@ucr.edu

Specialty section: This article was submitted to Microbiological Chemistry and Geomicrobiology, a section of the journal

Frontiers in Microbiology

Received: 30 June 2016 Accepted: 12 September 2016 Published: 23 September 2016

Citation:

Olson SL, Reinhard CT and Lyons TW (2016) Cyanobacterial Diazotrophy and Earth's Delayed

Oxygenation.

Front. Microbiol. 7:1526. doi: 10.3389/fmicb.2016.01526 been examined thoroughly. Here, we revisit the prevailing view that $\mathrm{N}_{2}$ fixation has always been able to keep pace with $\mathrm{P}$ supply and discuss the possibility that bioavailable $\mathrm{N}$, rather than $\mathrm{P}$, limited export production for extended periods of Earth's history. Based on the observation that diazotrophy occurs at the expense of oxygenesis in the modern ocean, we suggest that an $\mathrm{N}$-limited biosphere may be inherently less oxygenic than a P-limited biosphere-and that cyanobacterial diazotrophy was a primary control on the timing and tempo of Earth's oxygenation by modulating net biogenic $\mathrm{O}_{2}$ fluxes. We further hypothesize that negative feedbacks inhibit the transition between $\mathrm{N}$ and $P$ limitation, with the implication that the pervasive accumulation of $\mathrm{O}_{2}$ in Earth's ocean-atmosphere system may not have been an inevitable consequence of oxygenic photosynthesis by marine cyanobacteria.

Keywords: cyanobacteria, oxygen, denitrification, diazotrophy, boring billion

\section{INTRODUCTION}

Cyanobacteria are responsible for two major metabolic innovations: (1) oxygenic photosynthesis and (2) aerobic $\mathrm{N}_{2}$ fixation. The former initiated the protracted oxygenation of Earth's oceanatmosphere system and eventually set the stage for the evolution of complex animal life (reviewed by Lyons et al., 2014). The latter is also a remarkable achievement considering that nitrogenase, the enzyme responsible for cleaving the dinitrogen triple bond, is irreversibly inactivated by $\mathrm{O}_{2}$ (reviewed by Berman-Frank et al., 2003). Despite the apparent incompatibility of oxygenesis and diazotrophy, cyanobacteria dominate $\mathrm{N}_{2}$ fixation in the modern well-oxygenated ocean (Capone et al., 1997). This uniquely cyanobacterial ability to reconcile both environmental (exogenous) and photosynthetic (endogenous) $\mathrm{O}_{2}$ with $\mathrm{N}_{2}$ fixation (diazotrophy) acts to minimize the potential for biospheric $\mathrm{N}$ limitation and favors primary production that is broadly limited by the bioavailability 
of $\mathrm{P}$ in the modern ocean (Redfield, 1958; Tyrrell, 1999). Nevertheless, the details of the co-evolution of cyanobacterial innovation, the $\mathrm{O}_{2}$ content of the ocean-atmosphere system, and Earth's nutrient cycles during the Precambrian remain unclear. In particular, the origin of oxygenic photosynthesis and the oxygenation of Earth's atmosphere appear to be temporally decoupled, and there are major uncertainties regarding the primary controls on the timing and tempo of Earth's oxygenation (Lyons et al., 2014). The dynamics of the transition from a broadly anaerobic biosphere supported by $\mathrm{NH}_{4}{ }^{+}$and anaerobic diazotrophy to an aerobic biosphere dominated by $\mathrm{NO}_{3}{ }^{-}$ assimilation and $\mathrm{O}_{2}$-tolerant cyanobacterial diazotrophy are also poorly known (Fennel et al., 2005), muddling our understanding of the causal relationships at play between $\mathrm{O}_{2}$ production, oxygenation, and marine nutrient cycling.

Herein, we examine the metabolic capabilities of extant diazotrophic cyanobacteria in the context of recent constraints on the oceanographic conditions of the mid-Proterozoic $(\sim 1.8$ to 0.8 billion years ago or $\mathrm{Ga}$ ). We discuss the possibility that the spatiotemporal redox landscape of the mid-Proterozoic ocean would have been less than ideal for cyanobacterial $\mathrm{N}_{2}$ fixation, favoring widespread $\mathrm{N}$ scarcity rather than $\mathrm{P}$ limitation. We also explore the implications of $\mathrm{N}$ limitation for biogenic $\mathrm{O}_{2}$ fluxes from the marine biosphere, hypothesizing that cyanobacterial production would have been less oxygenic under the $\mathrm{O}_{2}$ and nutrient conditions that typified the mid-Proterozoic oceanpotentially providing a biological mechanism for stabilizing $\mathrm{pO}_{2}$ at values much lower than those of the modern Earth.

\section{EARTH'S REDOX EVOLUTION}

The origin of cyanobacterial oxygenic photosynthesis significantly predates the permanent and pervasive oxygenation of Earth's ocean-atmosphere system (Lyons et al., 2014). A growing collection of trace metal and isotopic records collectively indicates the accumulation of dissolved $\mathrm{O}_{2}$ in highly productive regions of the shallow ocean up to 50-500 million years before the initial oxygenation of the atmosphere $\sim 2.4 \mathrm{Ga}$ (e.g., Anbar et al., 2007; Kendall et al., 2010; Planavsky et al., 2014a) - a conclusion that is supported by recent biogeochemical models (Olson et al., 2013; Reinhard et al., 2013a). Evidence for dissolved $\mathrm{O}_{2}$ prior to the initial oxygenation of Earth's atmosphere in the early Paleoproterozoic includes $\mathrm{N}$ isotope records that capture the onset of coupled nitrification and denitrification, implying metabolic utilization of $\mathrm{O}_{2}$ in the oxidation of $\mathrm{NH}_{4}{ }^{+}$to $\mathrm{N}$ oxyanions in the surface ocean during the late Archean (Garvin et al., 2009; Godfrey and Falkowski, 2009). It is likely that dissolved $\mathrm{O}_{2}$ also accumulated, at least locally, in freshwater environments and within microbial mats, in isolation from prevailing oceanic and atmospheric conditions (Herman and Kump, 2005; Lalonde and Konhauser, 2015; Sumner et al., 2015). As such, inhibition of nitrogenase by $\mathrm{O}_{2}$ may have been an issue in both terrestrial and marine oxygen oases well before the first rise of atmospheric oxygen, and an initial inability to fix $\mathrm{N}_{2}$ aerobically to replenish bioavailable
$\mathrm{N}$ lost through denitrification may have limited cyanobacterial proliferation in the late Archean (Scott et al., 2011).

It is also clear that Earth's protracted oxygenation was not unidirectional and featured dramatic variability on a variety of timescales in addition to spatial heterogeneity (Lyons et al., 2014). Although relatively high atmospheric $\mathrm{pO}_{2}$ has been suggested during the Paleoproterozoic Lomagundi Event $~ 2.3-$ 2.1 Ga (Bekker and Holland, 2012; Rybacki et al., 2016), several geochemical records collectively suggest that environmental $\mathrm{O}_{2}$ levels subsequently fell precipitously at the onset of the ensuing Boring Billion $(\sim 1.8-0.8 \mathrm{Ga})$ and remained relatively low until the late Neoproterozoic (Planavsky et al., 2012; Partin et al., 2013). Recent $\mathrm{O}_{2}$ constraints suggest mid-Proterozoic $p \mathrm{O}_{2}$ of less than $10^{-3}$ times the present atmospheric level as a longterm average (Planavsky et al., 2014b), with the implication that the dissolved $\mathrm{O}_{2}$ landscape of the mid-Proterozoic ocean was not markedly different than that of the late Archean (Reinhard et al., 2016). The emerging view is that the surface ocean was likely characterized by low-micromolar $\mathrm{O}_{2}$ that was highly variable in space and time (Reinhard et al., 2016), while the deep ocean remained anoxic (Poulton and Canfield, 2011) - for the vast majority of Earth history. Indeed, despite evidence for oxygenation in the late Neoproterozoic (Sahoo et al., 2012; Planavsky et al., 2014b), clear evidence for pervasive and permanent oxygenation within the ocean is lacking until the Phanerozoic (Kendall et al., 2015; Sperling et al., 2015). In this view, the so-called Great Oxidation Event of the early Paleoproterozoic has relatively minor ecological implications compared to subsequent oxygenation in the late Neoproterozoic and early Phanerozoic. Meanwhile, it remains unclear why biospheric $\mathrm{O}_{2}$ production failed to result in stably oxygenated surface environments and deep ocean oxygenation for $\sim 2.5$ billion years after cyanobacterial emergence.

\section{OXYGENATION AND DENITRIFICATION}

The persistence of $\mathrm{O}_{2}$ stratification, that is, the widely held view that $\mathrm{O}_{2}$ was mostly restricted to the shallow ocean until the Paleozoic, has profound implications for the operation of the $\mathrm{N}$ cycle during Precambrian time. Denitrification, the reduction of bioavailable $\mathrm{NO}_{3}{ }^{-}$to $\mathrm{N}_{2}$ via anaerobic respiration of organic matter, results in a substantial loss of bioavailable $\mathrm{N}$ in $\mathrm{O}_{2}$-deficient environments. Anaerobic oxidation of $\mathrm{NH}_{4}{ }^{+}$ coupled to $\mathrm{NO}_{2}{ }^{-}$reduction (anammox) also represents a leak for bioavailable $\mathrm{N}$ as inert $\mathrm{N}_{2}$ (Kuypers et al., 2005). In the modern well-oxygenated ocean, denitrification and anammox are limited to organic-rich sediments and oxygen minimum zones (OMZs) underlying high-nutrient waters where the subsurface demand for respiratory electron acceptors locally exceeds $\mathrm{O}_{2}$ supply (Gruber and Sarmiento, 1997). Denitrification and anammox would also have been limited prior to the origin of oxygenic photosynthesis as the result of limited $\mathrm{NO}_{2}{ }^{-}$and $\mathrm{NO}_{3}{ }^{-}$synthesis in an anoxic ocean. The redox-stratified water column of the Proterozoic Earth, however, would have been particularly conducive to widespread loss of bioavailable $\mathrm{N}$, because surface oxygenation would have allowed oxidation of $\mathrm{NH}_{4}{ }^{+}$to $\mathrm{N}$ 
oxyanions by $\mathrm{O}_{2}$ in surface environments to support continued subsurface $\mathrm{N}_{2}$ synthesis via denitrification and anammox (Fennel et al., 2005; Garvin et al., 2009; Godfrey and Falkowski, 2009).

\section{OXYGENATION AND $\mathrm{N}_{2}$ FIXATION}

The likelihood of extensive loss of fixed $\mathrm{N}$ through denitrification requires a correspondingly large influx of bioavailable $\mathrm{N}$ via diazotrophy at steady-state; if $\mathrm{N}_{2}$ fixation cannot keep pace with denitrification, export production must decline until denitrification and $\mathrm{N}_{2}$ fixation are balanced (e.g., Deutsch et al., 2007). Thus, widespread denitrification may potentially modulate the long-term oxidation dynamics of Earth's ocean-atmosphere system by limiting the burial of reduced carbon and sulfur if $\mathrm{N}_{2}$ fixation was less efficient than today. Indeed, there are several reasons that the Proterozoic surface ocean may have been less than ideal for cyanobacterial diazotrophy. Based on the metabolic capabilities of extant cyanobacteria, we suggest that the low-level, spatially and temporally variable $\mathrm{O}_{2}$ concentrations that likely characterized the Proterozoic surface ocean would have posed a worst-case scenario for $\mathrm{N}_{2}$ fixation by cyanobacteria-thus allowing for the possibility of an $\mathrm{N}$-limited biosphere for much of Earth history.

Extant diazotrophic cyanobacteria differ dramatically in their ability to cope with environmental $\mathrm{O}_{2}$, and many $\mathrm{N}_{2}$ fixing cyanobacteria are actually obligate aerobes despite nitrogenase sensitivity to $\mathrm{O}_{2}$ (reviewed by Fay, 1992; Gallon, 1992). For these cyanobacteria, aerobic respiration provides: (1) a strategy for protecting nitrogenase by contributing to the maintenance of low intracellular $\mathrm{O}_{2}$ and (2) an energy source to support the demanding task of cleaving the dinitrogen triple bond while simultaneously maintaining $\mathrm{O}_{2}$ defense mechanisms. For example, despite the need for anoxic conditions within heterocysts, these differentiated cells are metabolically costly, and the rate at which $\mathrm{O}_{2}$ can diffuse into heterocysts can be an important control on the rate of $\mathrm{N}_{2}$ fixation in low $\mathrm{O}_{2}$ environments (Stal, 2009). Among modern heterocystous cyanobacteria, the metabolic machinery for $\mathrm{N}_{2}$ fixation appears to be optimized for present day air-saturated or even modestly elevated $\mathrm{O}_{2}$ concentrations (e.g., $\sim 300 \mu \mathrm{M}$ for Anabaena cylindrica; see Tomitani et al., 2006). Ambient $\mathrm{O}_{2}$ concentrations also appear to control both the rate and frequency of heterocyst growth (Kangatharalingam et al., 1992), with heterocysts grown under $\mathrm{O}_{2}$-replete conditions demonstrating lower sensitivity to environmental instability (e.g., diurnal fluctuations in $\mathrm{O}_{2}$ availability; Rippka and Stanier, 1978). In sum, the ability to cope with inhibitory levels of $\mathrm{O}_{2}$ via heterocystic cellular differentiation seems, rather ironically, to be favored by persistently elevated $\mathrm{O}_{2}$. These observations highlight the possibility that heterocystous diazotrophy may have been challenging for marine cyanobacteria for the vast majority of Earth history. Indeed, unambiguous marine heterocyst fossils are absent until the Phanerozoic (Golubic et al., 1995), and heterocystous cyanobacteria are relatively uncommon in welloxygenated environments of the modern pelagic ocean (Zehr, 2011).
The non-heterocystous cyanobacteria that are capable of aerobic diazotrophy are generally tolerant of lower $\mathrm{O}_{2}$ concentrations than the heterocystous cyanobacteria. Nonetheless, some non-heterocystous cyanobacteria are also obligate aerobes, and low $\mathrm{O}_{2}$ availability may also reduce the rate of non-heterocystous $\mathrm{N}_{2}$ fixation (reviewed by Fay, 1992). Most aerobic non-heterocystous diazotrophic cyanobacteria optimally fix $\mathrm{N}_{2}$ at dissolved $\mathrm{O}_{2}$ concentrations on the order of $\sim 10-50 \%$ of present marine levels (see Tomitani et al., 2006). Thus, it is likely that Proterozoic shallow marine dissolved $\mathrm{O}_{2}$ concentrations ( $\sim 1 \%$ of modern; Reinhard et al., 2016$)$ would have been suboptimal for diazotrophic cyanobacteria that were obligate aerobes. Meanwhile, even $\sim 1 \%$ of modern dissolved $\mathrm{O}_{2}$ is sufficient to completely inhibit anaerobic $\mathrm{N}_{2}$ fixation among the majority of microaerobic non-heterocystous cyanobacteria (Bergman et al., 1997) and the obligate anaerobes capable of diazotrophy (e.g., some methanogens; Murray and Zinder, 1984).

\section{N SCARCITY AND NET O $\mathrm{O}_{2}$ PRODUCTION}

Not all $\mathrm{O}_{2}$-tolerant, $\mathrm{N}_{2}$-fixing cyanobacteria meet the energetic demands of $\mathrm{N}_{2}$ fixation through aerobic respiration. Although $\mathrm{O}_{2}$ is not typically limiting in the open ocean today, one of the most successful marine diazotrophs, Trichodesmium, does not depend on exogenous $\mathrm{O}_{2}$ to respire stored carbohydrates. Instead, Trichodesmium is able to use its photosynthetic enzymes to power $\mathrm{N}_{2}$ fixation (reviewed by Bergman et al., 2013). However, because Trichodesmium performs diazotrophy at the expense of photosynthesis during daylight, midday $\mathrm{O}_{2}$ production is markedly reduced and potentially reversed when bioavailable $\mathrm{N}$ is limiting (Berman-Frank et al., 2001). Several other widespread unicellular marine cyanobacteria also fix $\mathrm{N}_{2}$ during the day using electron transfer from photosystem I (PSI)-and these cyanobacteria completely lack the ability to perform oxygenic photosynthesis (Zehr et al., 2008; Bothe et al., 2010; Tripp et al., 2010). These alternative strategies for coping with $\mathrm{N}$ scarcity would have been particularly advantageous if the ancient marine $\mathrm{O}_{2}$ landscape was not persistently favorable for either obligately aerobic or anaerobic $\mathrm{N}_{2}$ fixation. If PSI-dependent $\mathrm{N}_{2}$ fixation by $\mathrm{O}_{2}$ tolerant diazotrophic cyanobacteria was more common during Proterozoic time, cyanobacterial production may have been widely anoxygenic for much of Earth history. It follows that even if previous claims that the $\mathrm{C}$ isotope record precludes major changes in the burial of reduced organic carbon are correct (e.g., Holland, 2002), the $\mathrm{C}$ isotope record does not rule out major changes in net $\mathrm{O}_{2}$ fluxes from the marine biosphere through time.

This potential for reduced net oxygenesis in a low- $\mathrm{O}_{2}$ ocean is potentially exacerbated by the enhanced ecological significance of anoxygenic phototrophy coupled to the oxidation of $\mathrm{H}_{2} \mathrm{~S}$ (Johnston et al., 2009; Hamilton et al., 2016). Indeed, biomarkers and several inorganic proxy records point to local subsurface $\mathrm{H}_{2} \mathrm{~S}$ accumulation (euxinia) during the Proterozoic (Brocks et al., 2005; Scott et al., 2008; Lyons et al., 2009), despite the apparent persistence of iron-rich (ferruginous) 
conditions at depth (Planavsky et al., 2011; Poulton and Canfield, 2011). In addition to supporting greater anoxygenic production, euxinia may also increase the likelihood of nitrogenase metal cofactor limitation due to the burial of Mo in euxinic sediments (e.g., Anbar and Knoll, 2002)—even if euxinia was limited to only $\sim 1-10 \%$ of the seafloor (Reinhard et al., 2013b). Regardless, because anaerobic respiration using $\mathrm{SO}_{4}{ }^{2-}$ as an electron acceptor (sulfate reduction) yields less energy than denitrification, evidence for euxinia is synonymous with evidence for $\mathrm{NO}_{3}{ }^{-}$depletion (Boyle et al., 2013). The observation that euxinia was relatively common in both space and time during the Proterozoic is therefore fully consistent with the conclusion that $\mathrm{N}$ stress may have been problematic for the Proterozoic biosphere, as well as the assertion that the Proterozoic biosphere may have been less oxygenic.

\section{OXYGEN-NUTRIENT FEEDBACKS}

Whereas diazotrophy provides a pathway to alleviate $\mathrm{N}$ limitation, $\mathrm{P}$ is exclusively sourced to the ocean through crustal weathering. This inability of the marine biosphere to replenish $\mathrm{P}$ gives rise to the paradigm of a P-limited biosphere throughout Earth history (Redfield, 1958; Tyrrell, 1999). However, the assumption that cyanobacterial $\mathrm{N}_{2}$ fixation could keep pace with $\mathrm{P}$ supply during the Precambrian requires revisiting for reasons discussed above. In contrast with the prevailing view that $\mathrm{P}$ has limited marine productivity throughout Earth history, we hypothesize that prolonged $\mathrm{N}$ deficiency may have been a primary control on biospheric $\mathrm{O}_{2}$ fluxes and the tempo of Earth's oxygenation.

As long as the ocean remained stratified with respect to $\mathrm{O}_{2}$, subsurface anoxia would have allowed a positive coupling between surface oxygenation and denitrification: nitrification is enhanced as surface oxygen oases expand, allowing greater loss of fixed $\mathrm{N}$ through subsequent subsurface denitrificationpromoting $\mathrm{N}$ scarcity and providing a stabilizing negative feedback on biogenic $\mathrm{O}_{2}$ accumulation (Figure 1; also see Fennel et al., 2005). Complete alleviation of $\mathrm{N}$ scarcity via $\mathrm{N}_{2}$ fixation would be challenging for the reasons outlined above, which may result in reduced export production and organic $\mathrm{C}$ burial in response to oxygenation. Meanwhile, we argue that enhanced biospheric dependence on diazotrophy may also result in a reduction of net $\mathrm{O}_{2}$ production per mol organic $\mathrm{C}$ burial. Thus, minor oxygenation of a redox-stratified biosphere may strongly disfavor further oxygenation through the reduction of net biological $\mathrm{O}_{2}$ production.

The critical coupling between oxygenation and denitrification is reversed under $\mathrm{O}_{2}$-replete conditions. Following the oxygenation of the deep ocean, increases in $\mathrm{O}_{2}$ would tend to limit the areal extent of denitrifying conditions in the ocean, minimizing the likelihood of $\mathrm{N}$ stress and favoring $\mathrm{P}$ limitation (Fennel et al., 2005). Meanwhile, net $\mathrm{O}_{2}$ production would be expected to increase as the biospheric dependence on $\mathrm{N}_{2}$ fixation and the contribution of anoxygenic phototrophy to export production decreased.

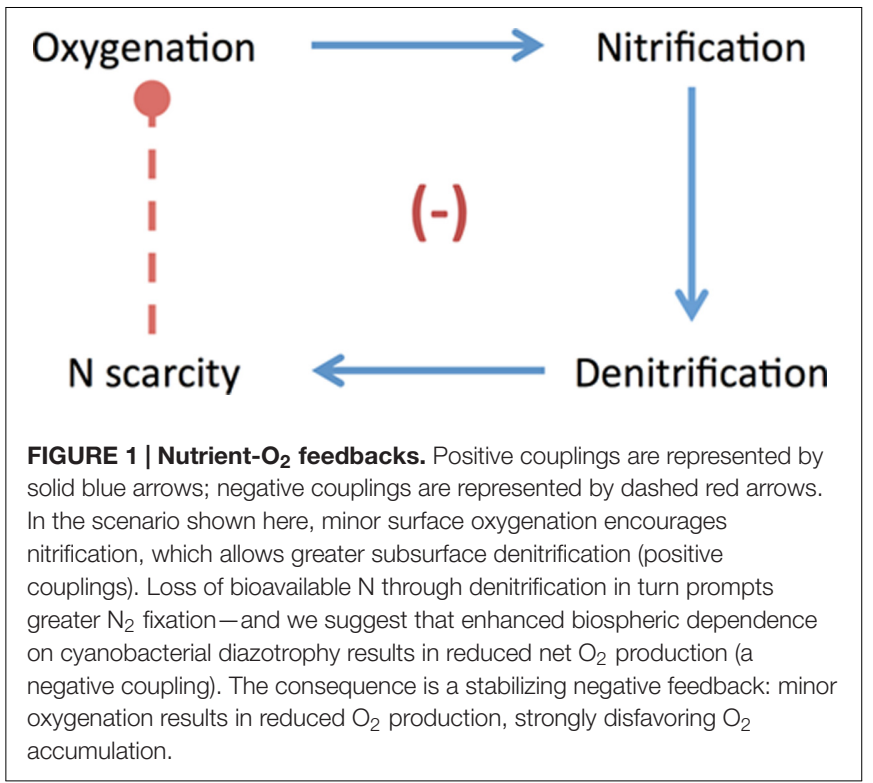

Thus, there may be two stable oxygen-nutrient states for the Earth system following the origin of oxygenic photosynthesis: an $\mathrm{O}_{2}$-stratified, $\mathrm{N}$-limited biosphere and an $\mathrm{O}_{2}$-replete, $\mathrm{P}$ limited biosphere (Anbar and Knoll, 2002; Fennel et al., 2005). Indeed, updated $C$ isotope models suggest a permanent increase in organic burial at the end of the Proterozoic (Krissansen-Totton et al., 2015), possibly consistent with the alleviation of $\mathrm{N}$ stress and the transition to a P-limited biosphere as the consequence of oxygenation in the late Neoproterozoic.

\section{CONCLUDING REMARKS}

Aerobic diazotrophy was a critical cyanobacterial innovation on par with oxygenic photosynthesis in terms of ecological impact, but it is likely that its environmental context and its contribution to global $\mathrm{N}$ cycling has varied dramatically through time. An important implication is that net biogenic $\mathrm{O}_{2}$ fluxes may have also varied through time. We hypothesize that low $\mathrm{O}_{2}$ availability may perpetuate low $\mathrm{O}_{2}$ conditions in the surface ocean, and anoxia at depth, by promoting extensive denitrification and the maintenance of conditions that are unfavorable for diazotrophy, both aerobic and anaerobic. Based on the success of anoxygenic diazotrophic cyanobacteria in the modern ocean, we further suggest that the most favorable cyanobacterial strategies for coping with $\mathrm{N}$ deficiency may have resulted in markedly reduced $\mathrm{O}_{2}$ production relative to today.

Enhanced biospheric dependence on cyanobacterial diazotrophy during the mid-Proterozoic, therefore, may explain the $\sim 2.5$ billion years delay between the Archean origin of oxygenic photosynthesis and the pervasive oxygenation of the ocean-atmosphere system in the Phanerozoic. Considering the likelihood of negative feedbacks that would tend to inhibit mitigation of global $\mathrm{N}$-limitation, the relatively recent transition 
away from a world in which $\mathrm{O}_{2}$ accumulation was spatially limited to oases within the surface ocean toward a more pervasively oxygenated ocean may not be readily understood as the inevitable consequence of continued photosynthetic $\mathrm{O}_{2}$ production in surface environments. Instead, the transition from an $\mathrm{O}_{2}$-stratified, $\mathrm{N}$-deficient marine biosphere to the broadly P-limited and well-oxygenated biosphere may require a yet unknown external perturbation to Earth's $\mathrm{O}_{2}$ cycle. Although uncertainties remain, it is clear that cyanobacteria have played a highly dynamic role in the protracted oxygenation of the Earth system throughout the Precambrian-extending well beyond their invention of oxygenic photosynthesis roughly three or more billion years ago.

\section{REFERENCES}

Anbar, A. D., Duan, Y., Lyons, T. W., Arnold, G. L., Kendall, B., Creaser, R. A., et al. (2007). A whiff of oxygen before the great oxidation event? Science 317, 1903-1906. doi: 10.1126/science. 1140325

Anbar, A. D., and Knoll, A. H. (2002). Proterozoic ocean chemistry and evolution: a bioinorganic bridge? Science 297, 1137-1142. doi: 10.1126/science.1069651

Bekker, A., and Holland, H. D. (2012). Oxygen overshoot and recovery during the early Paleoproterozoic. Earth Planet. Sci. Lett. 317, 295-304. doi: 10.1016/j.epsl.2011.12.012

Bergman, B., Gallon, J. R., Rai, A. N., and Stal, L. J. (1997). N2 fixation by non-heterocystous cyanobacteria. FEMS Microbiol. Rev. 19, 139-185. doi: 10.1016/S0168-6445(96)00028-9

Bergman, B., Sandh, G., Lin, S., Larsson, J., and Carpenter, E. J. (2013). Trichodesmium - a widespread marine cyanobacteria with unusual nitrogen fixation properties. FEMS Microbiol. Rev. 37, 286-302. doi: 10.1111/j.15746976.2012.00352.x

Berman-Frank, I., Lundgren, P., Chen, Y. B., Kupper, H., Kolber, Z., Bergman, B., et al. (2001). Segregation of nitrogen fixation and oxygenic photosynthesis in the marine cyanobacterium Trichodesmium. Science 294, 1534-1537. doi: 10.1126/science.1064082

Berman-Frank, I., Lundgren, P., and Falkowski, P. (2003). Nitrogen fixation and photosynthetic oxygen evolution in cyanobacteria. Res. Microbiol. 154, 157-164. doi: 10.1016/S0923-2508(03)00029-9

Bothe, H., Tripp, H. J., and Zehr, J. P. (2010). Unicellular cyanobacteria with a new mode of life: the lack of photosynthetic oxygen evolution allows nitrogen fixation to proceed. Arch. Microbiol. 192, 783-790. doi: 10.1007/s00203-0100621-5

Boyle, R. A., Clark, J. R., Poulton, S. W., Shields-Zhou, G., Canfield, D. E., and Lenton, T. M. (2013). Nitrogen cycle feedbacks as a control on euxinia in the mid-Proterozoic ocean. Nat. Commun. 4:1533. doi: 10.1038/ncomms2511

Brocks, J. J., Love, G. D., Summons, R. E., Knoll, A. H., Logan, G. A., and Bowden, S. A. (2005). Biomarker evidence for green and purple sulphur bacteria in a stratified Palaeoproterozoic sea. Nature 437, 866-870. doi: 10.1038/nature 04068

Capone, D. G., Zehr, J. P., Paerl, H. W., Bergman, B., and Carpenter, E. J. (1997). Trichodesmium, a globally significant marine cyanobacterium. Science 276, 1221-1229. doi: 10.1126/science.276.5316.1221

Deutsch, C., Sarmiento, J. L., Sigman, D. M., Gruber, N., and Dunne, J. P. (2007). Spatial coupling of nitrogen inputs and losses in the ocean. Nature 445, 163-167. doi: 10.1038 /nature05392

Fay, P. (1992). Oxygen relations of nitrogen fixation in cyanobacteria. Microbiol. Rev. 56, 340-373.

Fennel, K., Follows, M., and Falkowski, P. G. (2005). The co-evolution of the nitrogen, carbon and oxygen cycles in the Proterozoic ocean. Am. J. Sci. 305, 526-545. doi: 10.2475/ajs.305.6-8.526

Gallon, J. R. (1992). Reconciling the incompatible: N2 fixation and O2. New Phytol. 122, 571-609. doi: 10.1111/j.1469-8137.1992.tb00087.x

\section{AUTHOR CONTRIBUTIONS}

SO wrote the paper with insight from all authors.

\section{ACKNOWLEDGMENTS}

This material is based upon work supported by the National Aeronautics and Space Administration through the NASA Astrobiology Institute under Cooperative Agreement No. NNA15BB03A issued through the Science Mission Directorate. The authors also acknowledge support from the National Science Foundation Earth-Life Transitions program (TL and CR).

Garvin, G., Buick, R., Anbar, A. D., Arnold, G. L., and Kaufman, A. J. (2009). Isotopic evidence for an aerobic nitrogen cycle in the latest Archean. Science 323, 1045-1048. doi: 10.1126/science.1165675

Godfrey, L. V., and Falkowski, P. G. (2009). The cycling and redox state of nitrogen in the Archaean ocean. Nat. Geosci. 2, 725-729. doi: 10.1038/ngeo633

Golubic, S., Sergeev, V. N., and Knoll, A. H. (1995). Mesoproterozoic archaeoellipsoides: akinetes of heterocystous cyanobacteria. Lethaia 28, 285298. doi: 10.1111/j.1502-3931.1995.tb01817.x

Gruber, N., and Sarmiento, J. L. (1997). Global patterns of marine nitrogen fixation and denitrification. Global Biogeochem. Cycles 11, 235-266. doi: 10.1073/pnas.1322132111

Hamilton, T. L., Bryant, D. A., and Macalady, J. L. (2016). The role of biology in planetary evolution: cyanobacterial primary production in lowoxygen Proterozoic oceans. Environ. Microbiol. 18, 325-340. doi: 10.1111/14622920.13118

Herman, E. K., and Kump, L. R. (2005). Biogeochemistry of microbial mats under Precambrian environmental conditions: a modeling study. Geobiology 3, 77-92. doi: 10.1111/j.1472-4669.2005.00048.x

Holland, H. D. (2002). Volcanic gases, black smokers, and the great oxidation event. Geochim. Cosmochim. Acta 66, 3811-3862. doi: 10.1016/S00167037(02)00950-X

Johnston, D. T., Wolfe-Simon, F., Pearson, A., and Knoll, A. H. (2009). Anoxygenic photosynthesis modulated Proterozoic oxygen and sustained Earth's middle age. Proc. Natl Acad. Sci. U.S.A. 106, 16925-16929. doi: 10.1073/pnas.0909248106

Kangatharalingam, N., Priscu, J. C., and Paerl, H. W. (1992). Heterocyst envelop thickness, heterocyst frequency, and nitrogenase activity in Anabaeana flosaquae: influence of exogenous oxygen tension. J. Gen. Microbiol. 138, 26732678. doi: 10.1099/00221287-138-12-2673

Kendall, B., Komiya, T., Lyons, T. W., Bates, S. M., Gordon, G. W., Romaniello, S. J., et al. (2015). Uranium and molybdenum isotope evidence for an episode of widespread ocean oxygenation during the late Ediacaran Period. Geochim. Cosmochim. Acta 156, 173-193. doi: 10.1016/j.gca.2015. 02.025

Kendall, B., Reinhard, C. T., Lyons, T. W., Kaufman, A. J., Poulton, S. W., and Anbar, A. D. (2010). Pervasive oxygenation along late Archaean ocean margins. Nat. Geosci. 3, 647-652. doi: 10.1038/ngeo942

Krissansen-Totton, J., Buick, R., and Catling, D. C. (2015). A statistical analysis of the carbon isotope record from the Archean to Phanerozoic and implications for the rise of oxygen. Am. J. Sci. 315, 275-316. doi: 10.2475/04. 2015.01

Kuypers, M. M. M., Lavik, G., Woebken, D., Schmid, M., Fuchs, B. M., Amann, R., et al. (2005). Massive nitrogen loss from the Benguela upwelling system through anaerobic ammonium oxidation. Proc. Natl. Acad. Sci. U.S.A. 102, 6478-6483. doi: 10.1073/pnas.0502088102

Lalonde, S. V., and Konhauser, K. O. (2015). Benthic perspective on Earth's oldest evidence of oxygenic photosynthesis. Proc. Natl. Acad. Sci. U.S.A. 112, 995-1000. doi: 10.1073/pnas.1415718112 
Lyons, T. W., Anbar, A. D., Severmann, S., Scott, C., and Gill, B. C. (2009). Tracking euxinia in the ancient ocean: a multiproxy perspective and Proterozoic case study. Annu. Rev. Earth Planet. Sci. 37, 507-534. doi: 10.1146/annurev.earth.36.031207.124233

Lyons, T. W., Reinhard, C. T., and Planavsky, N. J. (2014). The rise of oxygen in Earth's early ocean and atmosphere. Nature 506, 307-315. doi: $10.1038 /$ nature 13068

Murray, P. A., and Zinder, S. H. (1984). Nitrogen fixation by a methanogenic archaebacterium. Nature 312, 284-286. doi: 10.1038/312284a0

Olson, S. L., Kump, L. R., and Kasting, J. F. (2013). Quantifying the areal extent and dissolved oxygen concentrations of Archean oxygen oases. Chem. Geol. 362, 35-43. doi: 10.1016/j.chemgeo.2013.08.012

Partin, C. A., Bekker, A., Planavsky, N. J., Scott, C. T., Gill, B. C., Li, C., et al. (2013). Large-scale fluctuations in Precambrian atmospheric and oceanic oxygen levels from the record of $U$ in shales. Earth Planet. Sci. Lett. 369, 284-293. doi: 10.1016/j.epsl.2013.03.031

Planavsky, N. J., Asael, D., Hofmann, A., Reinhard, C. T., Lalonde, S. V., Knudsen, A., et al. (2014a). Evidence for oxygenic photosynthesis half a billion years before the great oxidation event. Nat. Geosci. 7, 283-286. doi: $10.1038 /$ ngeo 2122

Planavsky, N. J., Bekker, A., Hofmann, A., Owens, J. D., and Lyons, T. W. (2012). Sulfur record of rising and falling marine oxygen and sulfate levels during the Lomagundi event. Proc. Natl. Acad. Sci. U.S.A. 109, 18300-18305. doi: 10.1073/pnas.1120387109

Planavsky, N. J., McGoldrick, P., Scott, C. T., Reinhard, C. T., Kelly, A. E., Chu, X., et al. (2011). Widespread iron-rich conditions in the mid-Proterozoic ocean. Nature 477, 448-452. doi: 10.1038/nature10327

Planavsky, N. J., Reinhard, C. T., Wang, X., Thomson, D., McGoldrick, P., Rainbird, R. H., et al. (2014b). Low mid-proterozoic atmospheric oxygen levels and the delayed rise of animals. Science 346, 635-638. doi: 10.1126/ science. 1258410

Poulton, S. W., and Canfield, D. E. (2011). Ferruginous conditions: a dominant feature of the ocean through Earth's history. Elements 7, 107-112. doi: 10.2113/gselements.7.2.107

Redfield, A. C. (1958). The biological control of chemical factors in the environment. Am. Sci. 46, 205-221.

Reinhard, C. T., Lalonde, S. V., and Lyons, T. W. (2013a). Oxidative sulfide dissolution on the early Earth. Chem. Geol. 362, 44-55. doi: 10.1016/ j.chemgeo.2013.10.006

Reinhard, C. T., Planavsky, N. J., Olson, S. L., Lyons, T. W., and Erwin, D. H. (2016). Earth's oxygen cycle and the evolution of metazoan life. Proc. Natl. Acad. Sci. U.S.A. 113, 8933-8938. doi: 10.1073/pnas.1521544113

Reinhard, C. T., Planavsky, N. J., Robbins, L. J., Partin, C. A., Gill, B. C., Lalonde, S. V., et al. (2013b). Proterozoic ocean redox and biogeochemical stasis. Proc. Natl. Acad. Sci. U.S.A. 110, 5357-5362. doi: 10.1073/pnas. 1208622110

Rippka, R., and Stanier, R. Y. (1978). The effects of anaerobiosis on nitrogenase synthesis and heterocyst development by nosocacean cyanobacteria. J. Gen. Microbiol. 105, 83-94. doi: 10.1099/00221287-105-1-83
Rybacki, K. S., Kump, L. R., Hanski, E. J., and Melezhik, V. A. (2016). Weathering during the great oxidation event: fennoscandia arctic Russia $2.06 \mathrm{Ga}$ ago. Precambrian Res. 275, 513-525. doi: 10.1016/j.precamres.2016.01.010

Sahoo, S. K., Planavsky, N. J., Kendall, B., Wang, W., Shi, X., Scott, C., et al. (2012). Ocean oxygenation in the wake of the Marinoan glaciation. Nature 489, 546-549. doi: 10.1038/nature11445

Scott, C. T., Bekker, A., Reinhard, C. T., Schnetger, B., Krapez, B., Rumble, D. I. I. I., et al. (2011). Late Archean euxinic conditions before the rise of atmospheric oxygen. Geology 39, 119-122. doi: 10.1126/science.1176711

Scott, C. T., Lyons, T. W., Bekker, A., Shen, Y., Poulton, S. W., Chu, X., et al. (2008). Tracing the stepwise oxygenation of the Proterozoic ocean. Nature 452, 456-460. doi: 10.1038/nature06811

Sperling, E. A., Wolock, C. J., Morgan, A. S., Gill, B. C., Kunzmann, M., Halverson, G. P., et al. (2015). Statistical analysis of iron geochemical data suggests limited late Proterozoic oxygenation. Nature 523, 451-454. doi: 10.1038/nature 14589

Stal, L. J. (2009). Is the distribution of nitrogen-fixing cyanobacteria in the oceans related to temperature? Environ. Microbiol. 11, 1632-1645. doi: 10.1111/j.17582229.2009.00016.x

Sumner, D. Y., Hawes, I., Mackey, T. J., Jungblut, A. D., and Doran, P. T. (2015). Antarctic microbial mats: a modern analog for Archean lacustrine oxygen oases. Geology 43, 887-890. doi: 10.1130/G36966.1

Tomitani, A., Knoll, A. H., Cavanaugh, C. M., and Ohno, T. (2006). The evolutionary diversification of cyanobacteria: molecular-phylogenetic and paleontological perspectives. Proc. Natl. Acad. Sci. U.S.A. 103, 5442-5447. doi: 10.1073/pnas.0600999103

Tripp, H. J., Bench, S. R., Turk, K. A., Foster, R. A., Desany, B. A., Niazi, F., et al. (2010). Metabolic streamlining in an open-ocean nitrogen-fixing cyanobacterium. Nature 464, 90-94. doi: 10.1038/nature 08786

Tyrrell, T. (1999). The relative influences of nitrogen and phosphorus on oceanic primary production. Nature 400, 525-531. doi: 10.1038/22941

Zehr, J. P. (2011). Nitrogen fixation by marine cyanobacteria. Trends Microbiol. 19, 162-173. doi: 10.1016/j.tim.2010.12.004

Zehr, J. P., Bench, S. R., Carter, B. J., Hewson, I., Niazi, F., Shi, T., et al. (2008). Globally distributed oceanic N2-fixing cyanobacteria lack oxygenic photosystem II. Science 322, 1110-1112. doi: 10.1126/science.1165340

Conflict of Interest Statement: The authors declare that the research was conducted in the absence of any commercial or financial relationships that could be construed as a potential conflict of interest.

Copyright (c) 2016 Olson, Reinhard and Lyons. This is an open-access article distributed under the terms of the Creative Commons Attribution License (CC BY). The use, distribution or reproduction in other forums is permitted, provided the original author(s) or licensor are credited and that the original publication in this journal is cited, in accordance with accepted academic practice. No use, distribution or reproduction is permitted which does not comply with these terms. 